This manuscript is a non-peer reviewed preprint submitted to EarthArXiv.

Title

\title{
Tectonics dominates over climatic and oceanographic factors in controlling the physiography of the Americas shelf-break at a continental scale
}

\section{Authors}

Euan L. Soutter, ${ }^{1 *}$ Ian A. Kane, ${ }^{1}$ David M. Hodgson ${ }^{2}$, Stephen S. Flint ${ }^{1}$

\section{Affiliations}

${ }^{1}$ Department of Earth and Environmental Science, University of Manchester, Manchester, M13 9PL, United Kingdom

${ }^{2}$ School of Earth and Environment, University of Leeds, Leeds, LS2 9JT, United Kingdom

*euan.soutter@manchester.ac.uk

\begin{abstract}
The continental shelf-break defines the boundary between shallow- and deep-ocean environments, and is modified by subaerial and submarine processes through geological time. The physiography of the shelf-break therefore records the cumulative influence of these processes, and dictates where, and how efficiently, particulates and pollutants are transported into the deep-ocean. Despite its importance, the continuous along-margin physiography of the shelf-break, and its link to subaerial and submarine processes, remains unquantified on a continental scale. Using a combination of bathymetric data, signal processing and machine learning, we quantify how the physiography of the shelf-break varies continuously along the Americas continental margin. Results show that tectonics exert a first-order control on shelf-break physiography, with the narrowest and deepest canyons associated with small and steep tectonically-active catchments, and steep and narrow shelves. This suggests a dominance of tectonics over climatic and oceanographic factors in shaping submarine geomorphology on a continental scale, supporting the view that particulates and pollutants are most efficiently captured from their source and dispersed to the deep ocean along active margins.
\end{abstract}

\section{MAIN TEXT}

\section{Introduction}

The shelf-break is a critical juncture for sediment transported into ocean basins, acting as the boundary between shallow- and deep-water (1), and is identified by an oceanward increase in gradient onto the continental slope $(2,3)$. Since the continental shelf-break links the shallow- and deep-ocean, and is dynamic due to sea-level and sediment supply fluctuations $(4,5)$, its physiography reflects the cumulative effect of processes occurring on land, the continental shelf and the continental slope through geological time. Consequently, the shelf-break area has differing magnitudes of alongmargin (along depositional-strike) relief, which influences how particulates are dispersed along and across continental margins in the present-day. If submarine canyons extend across the shelf-break $(3,6)$, then relief along the shelf-break will be greater, and particles will be more efficiently captured from the shelf and concentrated in deep-water. If shelfbreak relief is suppressed, then particles, such as plastic waste, are less likely to be captured close to their terrestrial source and may instead be transported tens of kilometres along and across the shelf before being captured and concentrated in deeper waters (7). Alternatively, they may be dispersed and deposited widely along the margin and not transported into deep water. 
A number of erosional, depositional and tectonic processes influence shelf-break relief. Erosion of the shelf-break occurs by rivers when the shelf is exposed, by gravityflows when the shelf is submerged, by grounded ice in polar environments and during glacial periods, and by slope failure in all cases (8). Gravity-driven flows on the shelf are induced by suspended sediment, and both temperature and salinity contrasts in the water column, with suspended sediment typically derived from rivers or glacial meltwater, or by resuspension of shelf sediment by temperature- or salinity-induced flows, waves, tides, or slope failure $(3,9,10)$. Depositional processes, such as delta progradation or carbonate platform growth (11), and tectonic processes, such as diapirism (12), faulting (13) or locking of tectonic plates at subduction zones (14), can also impact the physiography of the shelf-break. Over time, these processes contribute to the formation of submarine canyons, which are the dominant erosional features that incise the present-day shelf (3).

The influences of these processes on shelf and shelf-break physiography have been studied along sections of continental margins with similar tectonic and climatic conditions, including the northern Canadian passive margin (15), NE Atlantic passive margin (16) and western American active margin (17), through global mapping of shelfincising submarine canyons $(3,18)$, and through discrete morphological classifications of global continental shelves (6). However, the continuous impact of these processes on shelf-break relief along continental margins with vastly different tectonic and climatic settings has not been quantified. This limits our constraint on the dominant processes influencing submarine geomorphology, which reduces our ability to predict where particulates, such as terrigenous sediment, pollutants and organic carbon, are transferred most efficiently to deep ocean environments along continental margins in the present-day. Here, using bathymetric data, 17 geomorphic and environmental predictors, and machine learning regression, we aim to; 1) quantify the wavelengths and magnitudes of relief along the Americas continental shelf-break, and 2) assess the dominant predictors of shelf-break relief.

Much of the present-day continental shelf was periodically exposed during Quaternary sea-level lowstands (19), and there is a high prevalence of shelf-incising submarine canyons along active margins $(3,18)$. Therefore, we expect that: 1$)$ shelf-break bathymetries will follow similar geomorphological trends to those observed in subaerial topography, and 2) tectonically-active margins will have greater shelf-break relief. We therefore hypothesize that wavelengths of shelf-break relief will be shorter and amplitudes of shelf-break relief greater on steeper margins, as observed in fluvial systems (20), and that because tectonics is the root cause of these elevated slopes, the dominant predictor of shelf-break relief will be tectonics.

\section{Results}

Along the measured Americas shelf-break, 1446 negative peaks with greater than $100 \mathrm{~m}$ of prominence below the adjacent seafloor were identified, and their heights, widths and aspect ratios (width/height) measured. Of these, 363 were: 1) constrained by direct measurement on the GEBCO bathymetric grid, 2) within latitudinal limits relatively unaffected by glaciation, and 3) not excluded by pre-processing (Fig. 1; 2; S2; see 'Methods'). Given the ubiquity of canyons along shelves (3), and the difficulty in differentiating canyons from isolated scarps or seafloor deformation, each negative peak is herein termed a 'canyon'. Each measured canyon is therefore formed through: 1) headward erosion by landsliding (or a single landslide), 2) downslope, thalweg erosion by 
rivers and gravity flows, 3) seafloor deformation, or 4) a combination of these processes (Fig. 3).

Random forest regressions of 10 predictors (21), selected from 17 predictors via recursive feature elimination (22; see 'Methods'; Table 1), indicate that lower aspect-ratio canyons (narrow and deep) are best predicted by catchment area, median catchment seismic risk (a proxy for tectonic activity), shelf width, and proximity to rivers (Fig. 4A). Spearman rank correlations indicate how these predictors influence aspect ratios, with smaller catchments, more seismically-active catchments, narrow shelves, and greater proximity to rivers resulting in lower canyon aspect ratios (Fig 4B).

\section{Discussion}

Shelf-break relief is primarily predicted by catchment area, seismicity in the hinterland, shelf width (and therefore shelf gradient), and proximity to rivers. These properties are primarily controlled by continental margin tectonics, with tectonicallyactive margins tending to have small and steep catchments, with steep and narrow shelves $(3,5)$. This results from: 1$)$ tectonic uplift steepening fluvial catchments $(23)$, promoting the development of steep and narrow shelves (24), and 2) coastal uplift outpacing wave erosion (14). These properties dominate over oceanographic and climatic factors, suggesting present-day shelf-break relief is predicted at the first order by tectonics. This is consistent with fluvial geomorphology, where a similar dominance of tectonics over hydrological factors is observed on a continental scale (23).

Tectonically-active catchments may influence shelf-break relief by promoting the delivery of coarse-grained sediment to coastal environments (25), resulting in increased erosion of the shelf-break in proximity to these catchments. This pattern has been observed on the western North American margin, with high supplies of coarse-grained sediment and wave focusing resulting in an increased potential for canyons to incise landwards across the shelf (26), and shelf-incised canyons being more prevalent on active margins globally (3). While larger catchments on passive margins contribute vast quantities of sediment to continental margins, they are typically fine-grained and located many tens to hundreds of kilometres from the shelf-break in the present-day, thus reducing present-day shelf-break erosion (Fig. 2). The larger size of these catchments also results in large rivers that are more widely spaced along continental margins, thus focussing erosion in more localised areas of the shelf break.

Increased erosion of the shelf-break in response to elevated gradients is likely caused by increased shear stresses exerted on the bed by rivers and sediment gravity flows travelling across steeper shelves, resulting in greater vertical erosion of the shelf-break and narrower canyons (Fig. 5). Similar inverse relationships between slope and width have been observed in both submarine conduits (27) and tectonically-steepened fluvial channels (28). Submarine canyons have also been shown to incise farther across the shelf when formed on steep and narrow shelves (18). Lower-shelf gradients likely result in wider canyons because the potential for vertical erosion is reduced and the potential for lateral erosion and widening enhanced (29). While glacial influences are limited by excluding high-latitude shelves $\left(>50^{\circ}\right)$, it should be noted that some wide canyons may be formed by erosion beneath major marine-terminating ice sheets, such as the $\sim 50 \mathrm{~km}$ wide NE Atlantic Laurentian Channel observed at the beginning of the measured shelf-break (Fig. 2) (30).

The thickness of sedimentary cover on the shelf, primarily influenced by tectonics (31), may affect canyon morphology by modifying the stability and erodibility of the 
shelf. Shelves with thinner sedimentary cover, typical of active margins, are more likely to be composed of erodible continental lithosphere or bedrock, and as a result will have shelf-breaks that are less prone to retrogressive failure and less easily eroded by flows travelling across the shelf (Fig. 5). Retrogression and widening will also be reduced on active margins by 'seismic strengthening' of surficial sediments through seismic activity, which lessens the susceptibility of active margins to slope failure (32). Fluvial channels and glacial fjords have been shown to exhibit the same behaviour, with river width partially set by bank strength (33), and glacial fjords tending to be narrower and deeper when eroded into less-erodible gneisses and metasediments (34). Less-erodible substrates may also induce narrowing through steepening, resulting in greater shear stresses and greater vertical erosion, as seen in fluvial channels $(35,36,20)$.

Bathymetric studies suggest that canyons formed on steeper and narrower slopes were more able to erode across the shelf and maintain connection to the shoreline during recent sea-level rise (18). Canyons formed on wide and low-gradient shelves, typical of passive margins, have been stranded at the shelf-break and thus less affected by downslope erosion from subaerially-derived gravity flows in the present. These canyons have instead been dominated by: 1) retrogression and headward erosion, promoting widening, and/or 2) filling by hemipelagic, longshore, or dilute gravity flow deposits, promoting shallowing. This has been observed on the NE Atlantic margin, where Quaternary fluvial systems previously active on passive margin shelves are presently buried (37), and on the Southern Cascadian margin, where net-depositional, aggrading canyons have reduced relief compared to active, more erosional canyons (38). High supplies of fine-grained sediment from large catchments along passive margins will also act to heal relief across wide regions of the shelf (39). These depositional factors all act to reduce canyon aspect ratios and present-day shelf-break relief.

Since many of the present-day canyons identified were influenced by fluvial erosion when sea-level was $120 \mathrm{~m}$ lower during the Last Glacial Maximum, and large portions of continental shelves were exposed (19), parallels between subaerial and submarine erosion are expected. Contradictions do exist between these results and similar studies. For example, a global analysis of shelf valleys indicated that wider and deeper valleys occur with increasing discharge (40), but there is little influence of discharge on the canyon dimensions observed here. This is likely due to the canyons intersected by this study being formed by a combination of rivers, gravity flows, and slope failures (Fig. 4). Deformation of the seafloor by active faulting or diapirism, such as in the Gulf of California (41) or Gulf of Mexico (Fig. 3D), and canyons with morphological templates defined by underlying tectonic structure, such as the Californian Medocino Canyon (Fig. 3C) (42), also account for some of the negative peaks identified. This variety of processes will obscure scaling relationships between geometry and discharge, as not all of the measured canyons are formed purely by rivers or gravity flows.

The transition from continental shelf to continental slope is marked by the shelfbreak, the evolution of which controls the spatial and temporal transfer of particulates to deep oceans across continental margins. Since subaerial topography is heavily influenced by tectonic setting, we aimed to test whether shelf-break bathymetry is similarly influenced by tectonics, using the Americas as a continental-scale case study. Catchment seismicity is found to be the strongest predictor of shelf-break relief, with canyons formed on tectonically-active margins being narrower and deeper than canyons on tectonicallypassive margins. This is primarily attributed to: 1) high supplies of coarse-grained sediment from small, tectonically-active catchments forming erosive gravity flows that erode the shelf-break, and 2) tectonically-elevated gradients increasing shear stresses 
exerted on the shelf-break by gravity flows and rivers. These results suggest that tectonism dominates over local, climatic and oceanographic factors in sculpting the shelf on a continental-scale. Particulates delivered to tectonically-active margins are therefore transported more effectively from their source to deep-water than particulates delivered to passive margins, which are likely to be distributed more widely from their source by shore-parallel currents before burial on the shelf or transport and concentration in deepwater. This study therefore provides a first order predictor for constraining the delivery of particulates and pollutants to the deep ocean, which has implications for predicting the efficacy of sediment transport to deep-water through geological time, and for interpreting the stratigraphic record of deep-marine sedimentary systems.

\section{Materials and Methods \\ Experimental Design}

Wavelengths and amplitudes of relief were measured by sampling the depth $(Z)$ of the Americas shelf-break as defined by (3). The along-slope shelf-break profile was sampled at the 15 arc-second resolution of the GEBCO gridded-bathymetry (43) and along the vertices defined by (3). Depths were therefore measured from 156,069 points along the shelf-break at a median-spacing of $324 \mathrm{~m}$ (Fig. 1). Distances between points were measured using Vincenty's geodetic formulae (44), resulting in a continuous shelf-break profile spanning 51,386 km (Fig. 2A). The continental margin of the Americas was chosen as it has good bathymetric constraint, and transitions through tectonically-active and passive settings, thus allowing comparisons to be made between vastly different tectonic and climatic settings.

Individual peaks of erosion on the shelf-break were defined by a peak-finding algorithm (scipy.signal.find_peaks; 45) based on a cut-off of $100 \mathrm{~m}$ prominence below the adjacent seafloor, i.e. $100 \mathrm{~m}$ of vertical relief (Fig. 1B). Each peak is termed a 'submarine canyon' (see 'Results'). Canyon heights (amplitude of erosion) were measured as $75 \%$ of the peak prominence $(H)$, and widths (wavelength of erosion) were calculated by measuring the horizontal line length from the height of the canyon to the point where it intersects the seafloor in both directions $(W)$, i.e. $75 \%$ of the bank-full height and width of the canyon (Fig. 1B). From these width and depth measurements, aspect ratios were calculated $(A s=W / H)$. A $75 \%$ value was chosen to prevent the algorithm intersecting the seafloor unrealistically far from canyons with large prominences above adjacent canyons. As a consequence of the GEBCO grid being a stitched compilation of different datasources with different levels of constraint (43), only canyon thalwegs constrained by direct bathymetric measurements, such as soundings or Lidar, were included in the analysis. Canyons visually affected by bathymetric gridding effects were also excluded. In order to mitigate against glacial influences, canyons formed at high-latitudes $\left(>50^{\circ}\right)$ were also excluded. This resulted in 370 out of 1668 canyons being analysed.

\section{Geomorphic, tectonic and environmental indices}

In order to assess the influence of continental margin tectonics on the measured geometries, the shelf-width ( $S w=$ distance from canyon to nearest $0 \mathrm{~m}$ contour), shelf gradient $\left(\tan ^{-1}(Z / S w)\right)$, and sediment thickness at the shelf-break (31) were measured for each canyon, as these parameters are useful submarine proxies for tectonism (3) (Fig. 2). Shelves with thick accumulations of sediment at the shelf-break are termed 'thick' shelves, and shelves with thin accumulations of sediment at the shelf-break are termed 'thin' shelves. Shelf width and thickness were averaged every 100 points (median spacing $32.5 \mathrm{~km}$ ) using a Savitsky-Golay filter to better represent the regional shelf physiography 
and mitigate against any sharp variations that may bias the results. Calculating shelf gradient from the regional shelf width also prevented shelf gradient being overly biased toward deeper peaks.

Subaerial proxies were calculated by averaging onshore erodibility (46), average annual precipitation and temperature (47), and onshore seismic risk (PGA; peak-groundacceleration with $10 \%$ chance of exceedance in 50 years; 48) within individual drainage basins and assigning these values to outlet of the largest river within that basin

(HydroSHEDS; 49) (Fig. 2). Subaerial river gradients were calculated via the maximum relief of the drainage basin and length of the largest river. Distances from the river outlet to each canyon were then calculated (Fig. 2), with this distance acting as weight on catchment indices:

$$
w=\frac{1}{\sqrt{d_{r}}}
$$

where $d_{r}$ is the distance to the nearest river and $w$ is the weighting factor. Each index was multiplied by the weight, and was applied to account for the influence of a river on an individual canyon reducing with increasing distance from the river, i.e. a canyon $400 \mathrm{~km}$ away from a river will not be as affected by a river as much as a canyon $5 \mathrm{~km}$ away (Fig. $\mathrm{S} 1$; Fig. S2). An inverse square-root function is used to prevent riverine influence from decaying too rapidly away from the coast and biasing the results (Fig. S1). The influence of waves, tides, coastal relief and coastal erodibility on shelf physiography were assessed by pairing each canyon with its nearest Ecological Coastal Unit (50). Coastal relief was weighted analogously to the catchment indices, but with shelf width instead of distance to the nearest river as the denominator.

\section{Statistical analysis}

To test which of these variables are most important for predicting shelf-break relief, a random forest regression was performed (sklearn.ensemble.RandomForestRegressor; 21). Pre-processing of the data involved: 1) removal of outliers (data outside three standard deviations of the mean), resulting in $7 / 370$ canyons being excluded; and 2) k-nearest-neighbour imputation of missing data (sklearn.impute.KNNImputer). All of these input features are included in Table 1. The top ten most influential variables were selected via recursive feature elimination (sklearn.feature_selection.RFE; 22), and used as the final input features. From the regression, the top ten features were ranked by their permutation importance for predicting canyon aspect ratios based on 20 random shuffles (sklearn.inspection.permutation_importance; Fig. 4).

Two-tailed Kolmogorov-Smirnov tests were used to assess how significant the differences were between each ranked feature. Spearman rank correlations were also performed to indicate whether this influence was positive or negative, i.e. whether greater shelf gradients resulted in higher or lower aspect ratios (Fig. 4).

\section{References}

1. Stanley, D.J. and Wear, C.M., The "mud-line": An erosion--deposition boundary on the upper continental slope: Mar Geol, 28, M19 - M29, (1978).

2. Mitchell, N.C. and Huthnance, J.M., Oceanographic currents and the convexity of the uppermost continental slope. J Sed Res. 78, 29-44, (2008). 
3. Harris, P.T., Macmillan-Lawler, M., Rupp, J. and Baker, E.K., Geomorphology of the oceans: Mar Geol, 352, 4-24. (2014)

4. Blum, M., and Hattier-Womack, J., Climate change, sea-level change, and fluvial sediment supply to deepwater depositional systems: external controls on deepwater depositional system. SEPM Spec. Pub. 92, 15-39, (2009)

5. Nyberg, B., Helland-Hansen, W., Gawthorpe, R.L., Sandbakken, P., Eide, C.H., Sømme, T., Hadler-Jacobsen, F. and Leiknes, S., Revisiting morphological relationships of modern source-to-sink segments as a first-order approach to scale ancient sedimentary systems: Sed Geol, 373, 111-133, (2018)

6. Harris, P.T. and Macmillan-Lawler, M., Global overview of continental shelf geomorphology based on the SRTM30_PLUS 30-arc second database. Seafloor Mapping along Continental Shelves, 169-190, (2016)

7. Zhong, G. and Peng, X., Transport and accumulation of plastic litter in submarine canyons - The role of gravity flows. Geology. 49, 581-586, (2021)

8. Vanney, J.R., Stanley, D.J., 1983, Shelfbreak physiography: an overview. In: Stanley, D.J., Moore, G.T. (Eds.), The Shelf Break: Critical Interface on Continental Margins. SEPM Spec. Pub. 33, 1-24, (1983).

9. Wright, L.D. and Friedrichs, C.T., Gravity-driven sediment transport on continental shelves: A status report. Cont Shelf Res. 26, 2092-2107, (2006)

10. Flood, R.D., Hiscott, R.N. and Aksu, A.E., Morphology and evolution of an anastomosed channel network where saline underflow enters the Black Sea. Sedimentology. 56, 807839, (2009)

11. Gischler, E., Quaternary reef response to sea-level and environmental change in the western Atlantic. Sedimentology. 62, 429-465, (2015).

12. Rowan, M.G., Ratliff, R.A., Trudgill, B.D. and Duarte, J.B., Emplacement and evolution of the Mahogany salt body, central Louisiana outer shelf, northern Gulf of Mexico. AAPG Bulletin. 85, 947-969, (2001).

13. McNeill, L.C., Piper, K.A., Goldfinger, C., Kulm, L.D. and Yeats, R.S., Listric normal faulting on the Cascadia continental margin. J. Geophys. Res. Solid Earth. 102, 1212312138, (1997).

14. Malatesta, L.C., Bruhat, L., Finnegan, N.J. and Olive, J.A.L., Co-location of the downdip end of seismic coupling and the continental shelf break. J. Geophys. Res. Solid Earth. 126, e2020JB019589, (2018).

15. Forest, A., Osborne, P.D., Curtiss, G. and Lowings, M.G., Current surges and seabed erosion near the shelf break in the Canadian Beaufort Sea: A response to wind and ice motion stress. J Mar Syst. 160, 1-16, (2016).

16. Brothers, D.S., Uri, S., Andrews, B.D. and Chaytor, J.D., Geomorphic characterization of the US Atlantic continental margin: Mar Geol, 338, 46-63, (2013).

17. Smith, M.E., Finnegan, N.J., Mueller, E.R. and Best, R.J., Durable terrestrial bedrock predicts submarine canyon formation. Geophys. Res. Lett. 44, 10-332, (2017).

18. Bernhardt, A. and Schwanghart, W., Where and Why Do Submarine Canyons Remain Connected to the Shore During Sea-Level Rise? Insights From Global Topographic Analysis and Bayesian Regression. Geophys. Res. Lett. 48, e2020GL092234, (2021).

19. Miller, K.G., Browning, J.V., Schmelz, W.J., Kopp, R.E., Mountain, G.S. and Wright, J.D., Cenozoic sea-level and cryospheric evolution from deep-sea geochemical and continental margin records: Sci. adv. 6, eaaz1346, (2020)

20. Finnegan, N.J., Roe, G., Montgomery, D.R. and Hallet, B., Controls on the channel width of rivers: Implications for modeling fluvial incision of bedrock. Geology. 33, 229-232, (2005). 
21. Pedregosa, F., Varoquaux, G., Gramfort, A., Michel, V., Thirion, B., Grisel, O., Blondel, M., Prettenhofer, P., Weiss, R., Dubourg, V. and Vanderplas, J., 2011. Scikit-learn: Machine learning in Python. J Mach Learn Res. 12, 2825-2830, (2011).

22. Guyon, I., Weston, J., Barnhill, S., and Vapnik, V., Gene selection for cancer classification using support vector machines. Machine Learning. 46, 389-422, (2002).

23. Seybold, H., Berghuijs, W.R., Prancevic, J.P. and Kirchner, J.W., Global dominance of tectonics over climate in shaping river longitudinal profiles. Nat Geo. 1-5, (2021).

24. Blum, M., Martin, J., Milliken, K. and Garvin, M., Paleovalley systems: insights from Quaternary analogs and experiments. Earth Sci Rev. 116, 128-169, (2013).

25. Milliman, J.D. and Syvitski, J.P., Geomorphic/tectonic control of sediment discharge to the ocean: the importance of small mountainous rivers. The Journal of Geology. 100, 525544, (1992).

26. Smith, M.E., Werner, S.H., Buscombe, D., Finnegan, N.J., Sumner, E.J. and Mueller, E.R., Seeking the shore: Evidence for active submarine canyon head incision due to coarse sediment supply and focusing of wave energy. Geophys. Res. Lett. 45, 12-403, (2018).

27. Lemay, M., Grimaud, J.L., Cojan, I., Rivoirard, J. and Ors, F., Geomorphic variability of submarine channelized systems along continental margins: Comparison with fluvial meandering channels. Mar Pet Geol. 115, 104295, (2020).

28. Whittaker, A.C., Cowie, P.A., Attal, M., Tucker, G.E. and Roberts, G.P., Bedrock channel adjustment to tectonic forcing: Implications for predicting river incision rates. Geology. 35, 103-106, (2007).

29. Wellner, R.W. and Bartek, L.R., The effect of sea level, climate, and shelf physiography on the development of incised-valley complexes: a modern example from the East China Sea. J Sed Res. 73, 926-940, (2003).

30. Piper, D. and Macdonald, A., Timing and position of Late Wisconsinan ice-margins on the upper slope seaward of Laurentian Channel. Géographie physique et Quaternaire. 55, 131-140, (2001).

31. Straume, E.O., Gaina, C., Medvedev, S., Hochmuth, K., Gohl, K., Whittaker, J.M., Abdul Fattah, R., Doornenbal, J.C. and Hopper, J.R., GlobSed: Updated total sediment thickness in the world's oceans: Geochem. Geophys. Geosyst. 20, 1756-1772, (2019).

32. Sawyer, D.E. and DeVore, J.R., Elevated shear strength of sediments on active margins: Evidence for seismic strengthening. Geophys. Res. Lett. 42, 10-216, (2015).

33. Dunne, K.B. and Jerolmack, D.J., What sets river width? Sci. adv. 6, eabc1505, (2020).

34. Bernard, M., Steer, P., Gallagher, K., \& Egholm, D. L., The impact of lithology on fjord morphology. Geophys. Res. Lett. 48, e2021GL093101, (2021).

35. Moglen, G.E. and Bras, R.L., The effect of spatial heterogeneities on geomorphic expression in a model of basin evolution. Water. Resour. Res. 31, 2613-2623, (1995).

36. Duvall, A., Kirby, E. and Burbank, D., Tectonic and lithologic controls on bedrock channel profiles and processes in coastal California. J. Geophys. Res. Earth. Surf. 109, (2004).

37. Nordfjord, S., Goff, J.A., Austin Jr, J.A. and Sommerfield, C.K., Seismic geomorphology of buried channel systems on the New Jersey outer shelf: assessing past environmental conditions: Mar Geol, 214, 339-364, (2005).

38. Hill, J.C., Watt, J.T., Brothers, D.S. and Kluesner, J.W., Submarine canyons, slope failures and mass transport processes in southern Cascadia: GSL Spec. Pub. 500, 453-475, (2020).

39. O'Grady, D.B., Syvitski, J.P., Pratson, L.F. and Sarg, J.F., Categorizing the morphologic variability of siliciclastic passive continental margins. Geology. 28, 207-210, (2000). 
40. Wang, R., Colombera, L. and Mountney, N.P., Geological controls on the geometry of incised-valley fills: Insights from a global dataset of late-Quaternary examples. Sedimentology. 66, 2134-2168, (2019).

41. Persaud, P., Stock, J.M., Steckler, M.S., Martín-Barajas, A., Diebold, J.B., GonzálezFernández, A. and Mountain, G.S., Active deformation and shallow structure of the Wagner, Consag, and Delfin basins, northern Gulf of California, Mexico. J. Geophys. Res. Solid Earth, 108c, (2003).

42. Sumner, E.J. and Paull, C.K., Swept away by a turbidity current in Mendocino submarine canyon, California: Geophys. Res. Lett., 41, 7611-7618, (2014).

43. Tozer, B., Sandwell, D.T., Smith, W.H., Olson, C., Beale, J.R. and Wessel, P., Global bathymetry and topography at 15 arc sec: SRTM15+. Earth Space Sci, 6, 1847-1864, (2019).

44. Vincenty, T., Direct and inverse solutions of geodesics on the ellipsoid with application of nested equations. Survey review. 23, 88-93, (1975).

45. Virtanen, P., Gommers, R., Oliphant, T.E., Haberland, M., Reddy, T., Cournapeau, D., Burovski, E., Peterson, P., Weckesser, W., Bright, J. and van der Walt, S.J., SciPy 1.0: fundamental algorithms for scientific computing in Python. Nat. methods. 17, 261-272, (2020).

46. Moosdorf, N., Cohen, S. and von Hagke, C., A global erodibility index to represent sediment production potential of different rock types. Appl Geogr. 101, 36-44, (2018).

47. Fick, S.E. and Hijmans, R.J., WorldClim 2: new 1-km spatial resolution climate surfaces for global land areas. Int J Climatol. 37, 4302-4315, (2017).

48. Giardini, D., Grünthal, G., Shedlock, K. M., and Zhang, P., The GSHAP global seismic hazard map. Annals of Geophysics. 42, 1225-1230, (1999).

49. Lehner, B., Verdin, K., Jarvis, A. 2008, New global hydrography derived from spaceborne elevation data. Eos. Transactions. AGU. 89, 93-94, (2008).

50. Sayre, R., S. Noble, S. Hamann, R. Smith, D. Wright, S. Breyer, K. Butler, K. Van Graafeiland, C. Frye, D. Karagulle, D. Hopkins, D. Stephens, K. Kelly, Z, basher, D. Burton, J. Cress, K. Atkins, D. van Sistine, B. Friesen, B. Allee, T. Allen, P. Aniello, I Asaad, M. Costello, K. Goodin, P. Harris, M. Kavanaugh, H. Lillis, E. Manca, F. MullerKarger, B. Nyberg, R. Parsons, J. Saarinen, J. Steiner, and A. Reed, A new 30 meter resolution global shoreline vector and associated global islands database for the development of standardized global ecological coastal units. Journal of Operational Oceanography - A Special Blue Planet Edition, (2018).

\section{Acknowledgments}

\section{Funding:}

BP
Aker BP
BHP
CNOOC
Hess
Murphy
Neptune Energy
Vår Energi
Wintershall DEA.

Author contributions: 
Conceptualization: ES, IK, DH, SF

Methodology: ES

Investigation: ES

Visualization: ES

Supervision: IK, DH, SF

Writing — original draft: ES

Writing — review \& editing: IK, DH, SF

Competing interests: Authors declare that they have no competing interests.

Data and materials availability: All data are available in the main text or the supplementary materials.

Figures and Tables 

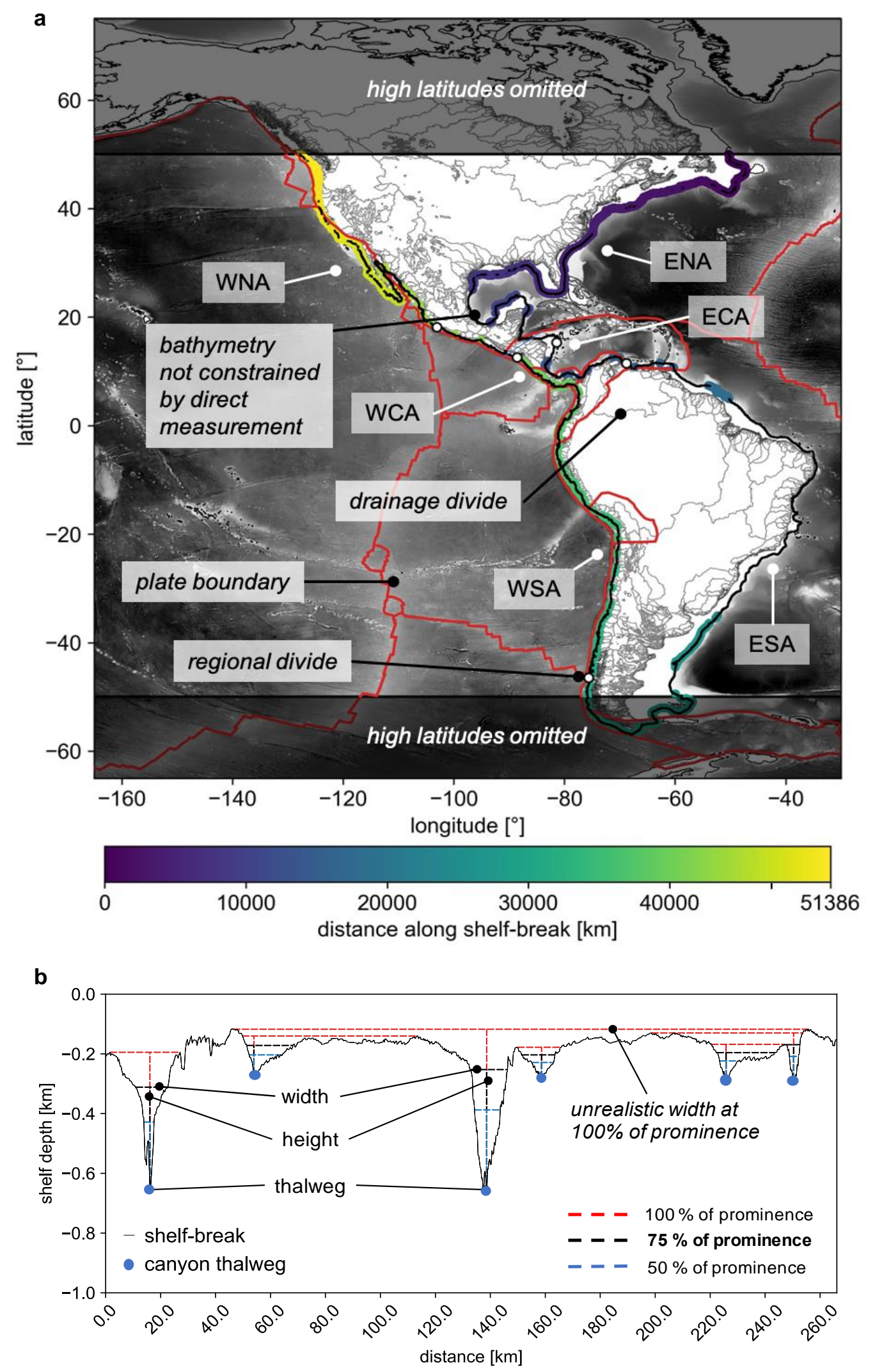
Fig. 1. Map of shelf-break extent and canyon mapping method. (A) Extent of the measured shelf-break along the continental margin of the Americas. Grey lines indicate drainage basins (HydroSHEDS; Lehner et al. 2008), and red lines indicate plate boundaries. ENA; eastern North America, ECA; eastern Central America, ESA; eastern South America, ESA; WNA; western North America, WCA; western Central America, WSA; western South America. (B) Negative peaks identified by the peak-finding algorithm based on a cut-off of $100 \mathrm{~m}$ prominence below the adjacent the seafloor. Height and widths measurements were taken at $75 \%$ of this prominence to prevent canyon dimensions being unrealistically large. 

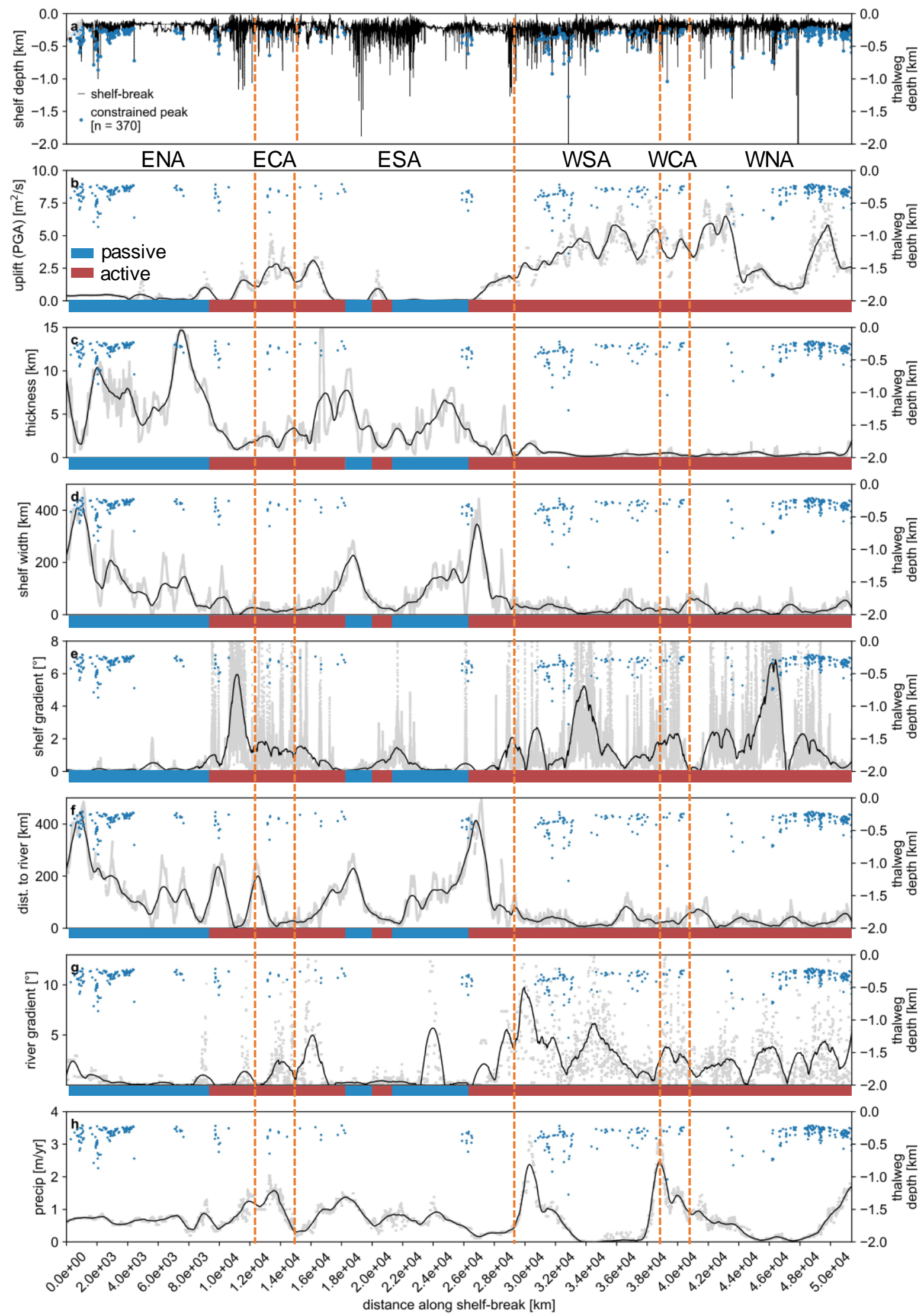
Fig. 2. Shelf-break profile, mapped canyons, and selected subaerial and submarine indices. A Savitsky-Golay filter over 5001 points is used to average values (solid back line). Raw data are shown in grey points, and canyon thalweg depths are shown in blue points. Margins are defined as 'active' or 'passive' based on terrestrial seismic risk data (Giardini et al. 1999), i.e. active margins have higher seismic risk. ENA; eastern North America, ECA; eastern Central America, ESA; eastern South America, ESA; WNA; western North America, WCA; western Central America, WSA; western South America. 

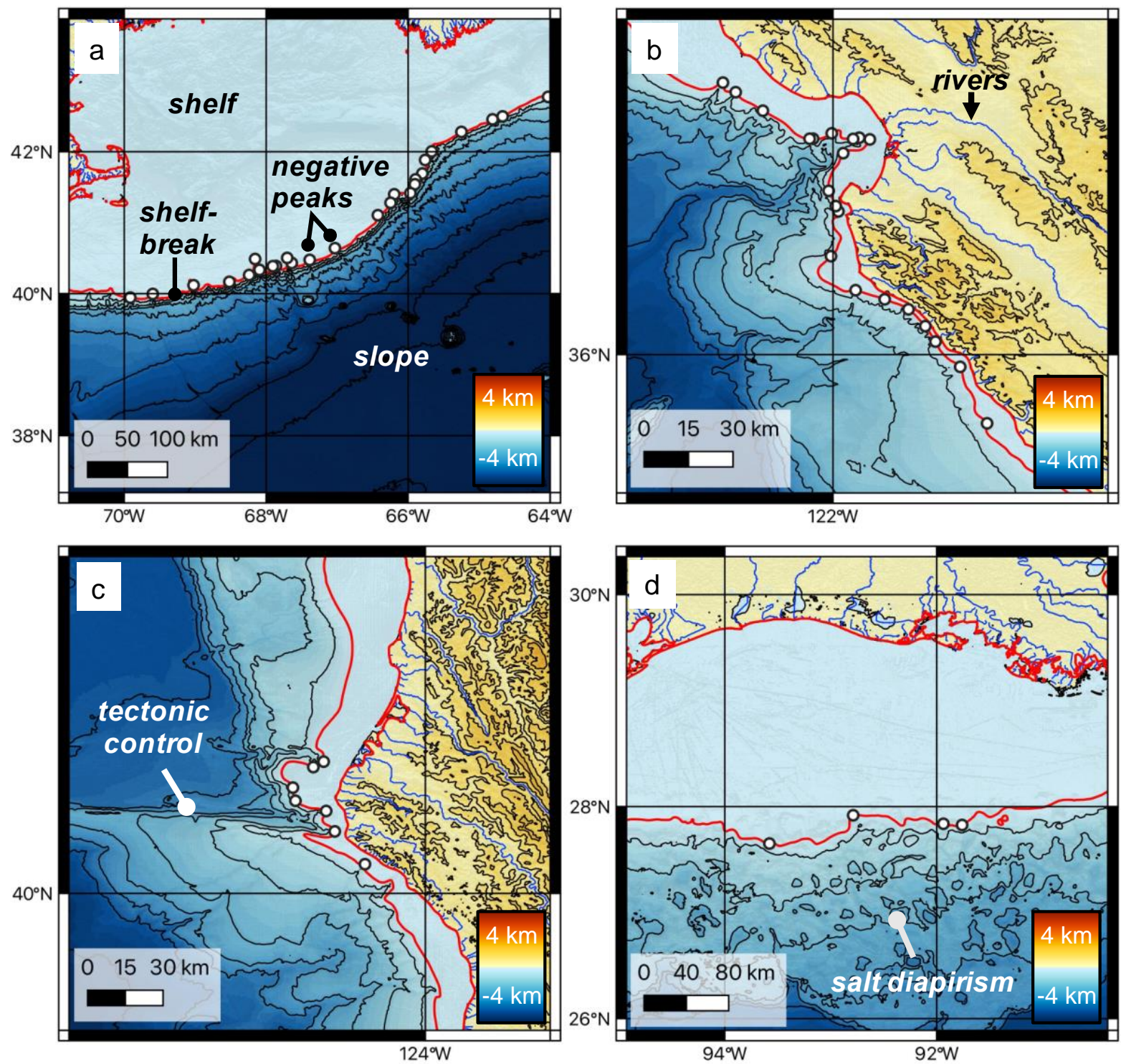

Fig. 3. Maps of the shelf-break (red line) (Harris et al. 2014) and negative peaks identified and analysed by this study (white dots). Most peaks are submarine canyons, illustrated by examples from NE America (A) and NW America (B). Some peaks are influenced by tectonics, such as canyons exploiting tectonic faults at the Mendocino triple junction (C), and salt diapirism in the Gulf of Mexico (D). 

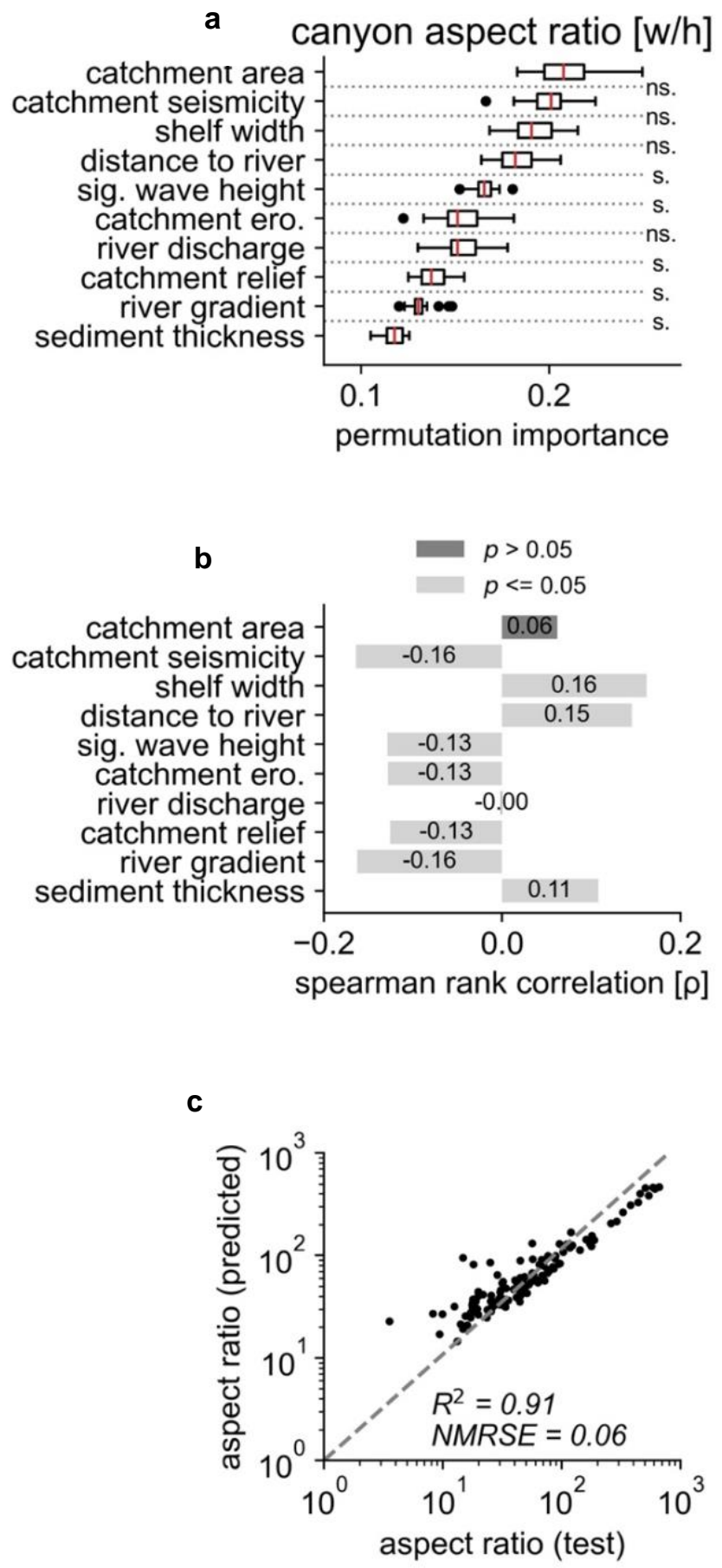

Fig. 4. Random forest regression results. (A) The top ten variables for predicting canyon aspect ratios after 20 random shuffles of the fitted model. Canyon aspect ratios are mainly predicted by catchment area and seismicity. The box extends from lower to upper quartiles, and the vertical red line is the median. Whiskers shows the range of the data, and black circles show outliers. Annotation ' $\mathrm{s}$ ' denotes two-tailed Kolmogorov-Smirnov p-values $<0.05$ (significant), 'ns' denotes p-values $<0.05$ (not-significant). ero.; erodibility, sig.; significant. (B) Spearman rank correlations of each variable against aspect ratio. (C) Aspect ratios from the test subset versus aspect ratios predicted by the model trained on a training subset $(0.77 / 0.33$ traintest-split). NMRSE $=$ normalised root mean squared error, $\mathrm{R}^{2}=$ coefficient of determination. 


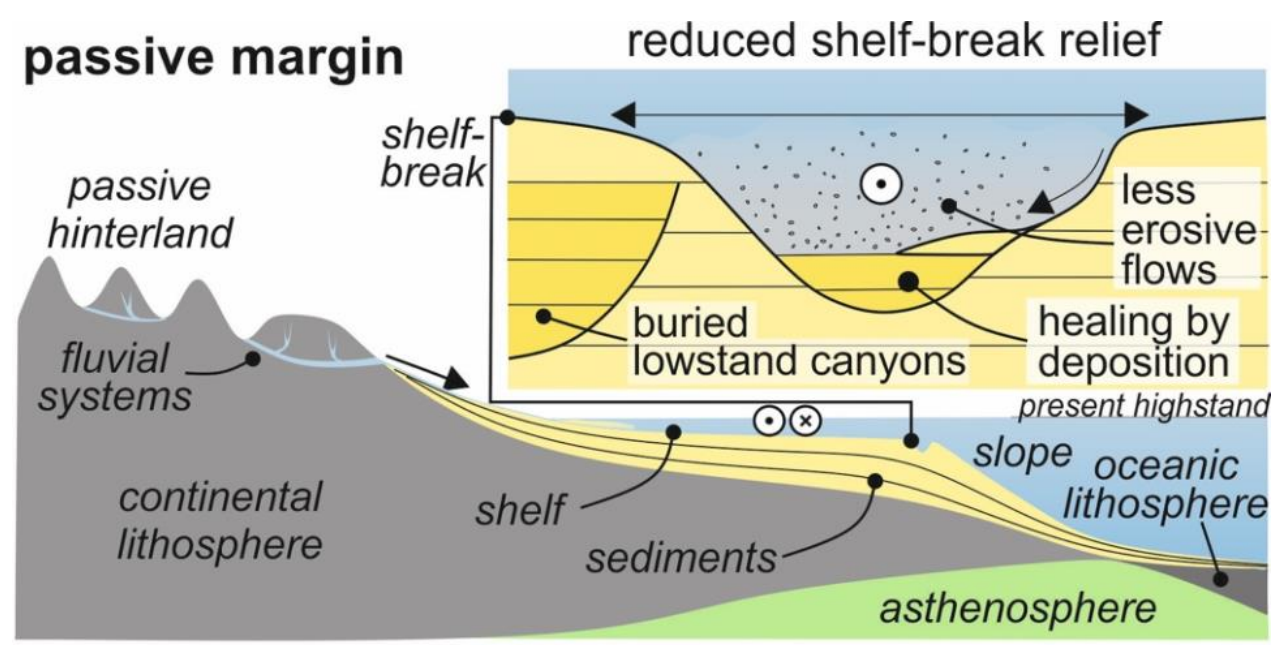

\section{active margin}

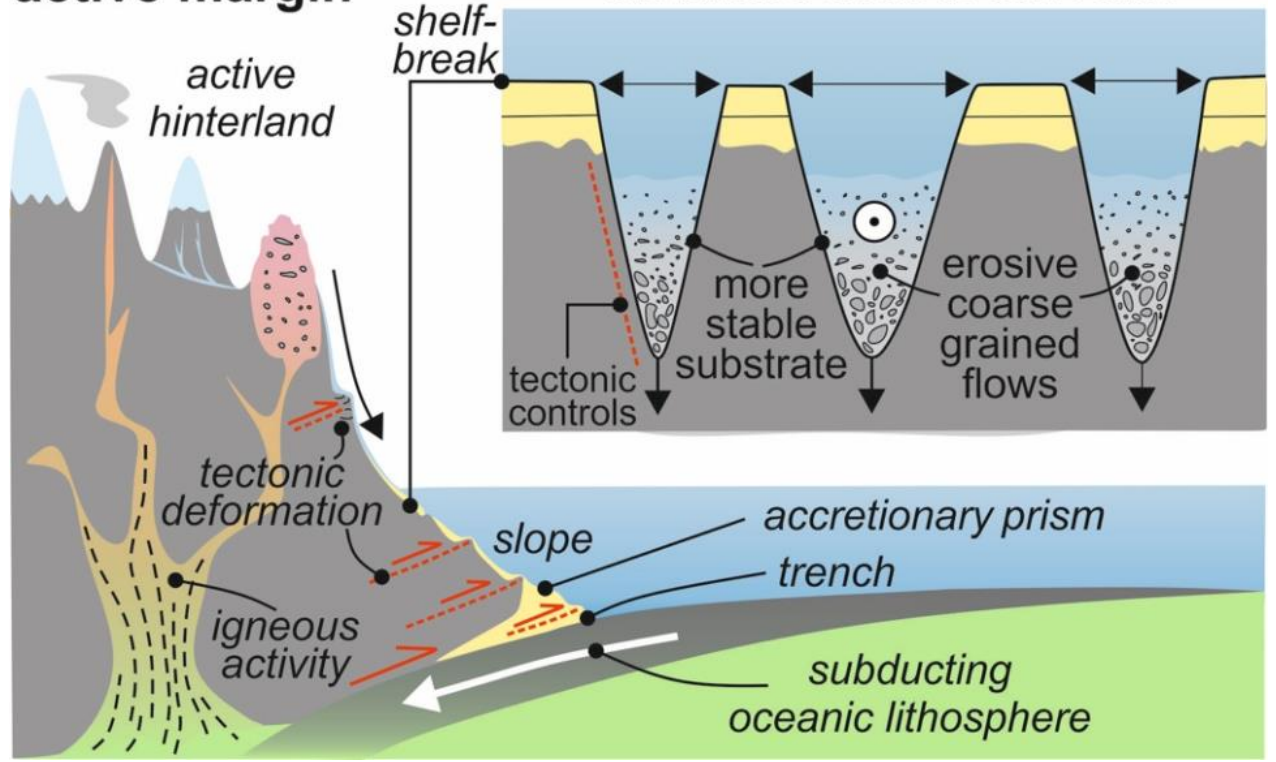

Figure 5: Generic model for submarine canyon geometries on tectonically-passive versus active margins. Active margins tend to be steeper and subject to more erosive, coarse grains flows, therefore canyons are deeper and narrower. Passive margins tend have lower-gradients and be subject to finergrained flows, or completely abandoned, in the present, therefore canyons are shallower and wider. Passive margins also tend to have thick accumulations of erodible and unstable sediment, increasing the ability of submarine canyons to erode laterally.

Fig. 5. Generic model for submarine canyon geometries on tectonically-passive versus active margins. Active margins tend to be steeper and subject to more erosive, coarse grains flows, therefore canyons are deeper and narrower. Passive margins tend have lower-gradients and be subject to finer-grained flows, or completely abandoned, in the present, therefore canyons are shallower and wider. Passive margins also tend to have thick accumulations of erodible and unstable sediment, increasing the ability of submarine canyons to erode laterally. 


\title{
Supplementary Materials for \\ Tectonics dominates over climatic and oceanographic factors in controlling the physiography of the Americas shelf-break at a continental scale
}

\author{
Euan L. Soutter, Ian A. Kane, David M. Hodgson, Stephen S. Flint \\ *Corresponding author. Email: euan.soutter@manchester.ac.uk
}

\section{This PDF file includes:}

Figs. S1 to S2

Tables $\mathrm{S} 1$ to $\mathrm{S} 2$

Data S1 

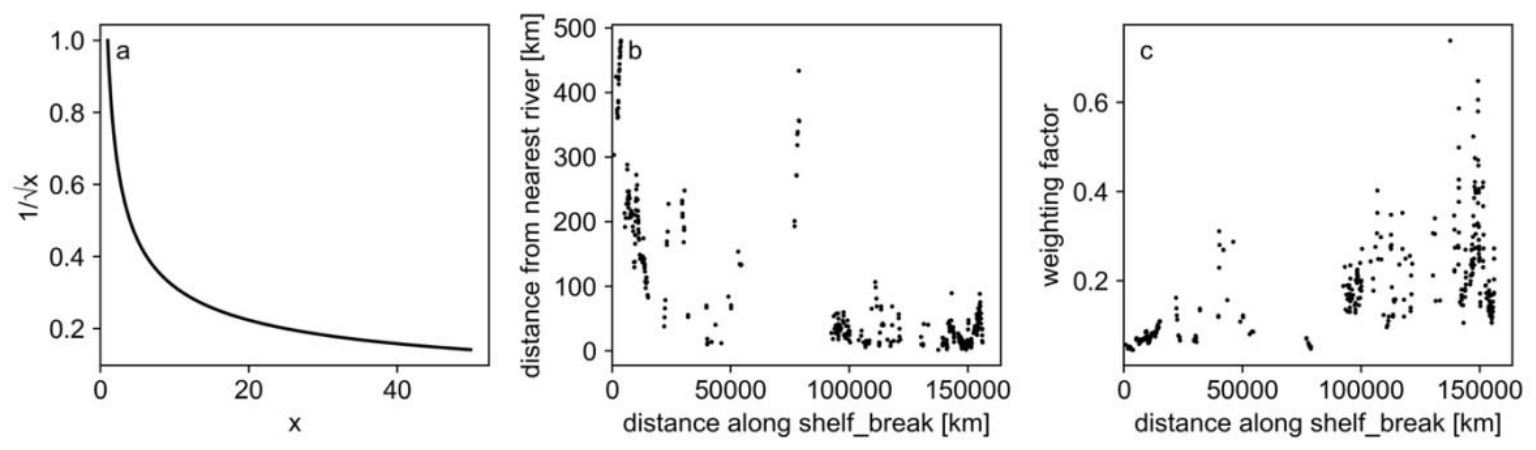

524 Fig. S1 (A) example of weighted function, (B) distance along shelf-break versus distance to river $525\left(\boldsymbol{d}_{\boldsymbol{r}}\right),(\mathbf{C})$ distance along shelf-break versus the weighting factor $\left(1 / \sqrt{\boldsymbol{d}_{\boldsymbol{r}}}\right)$. 

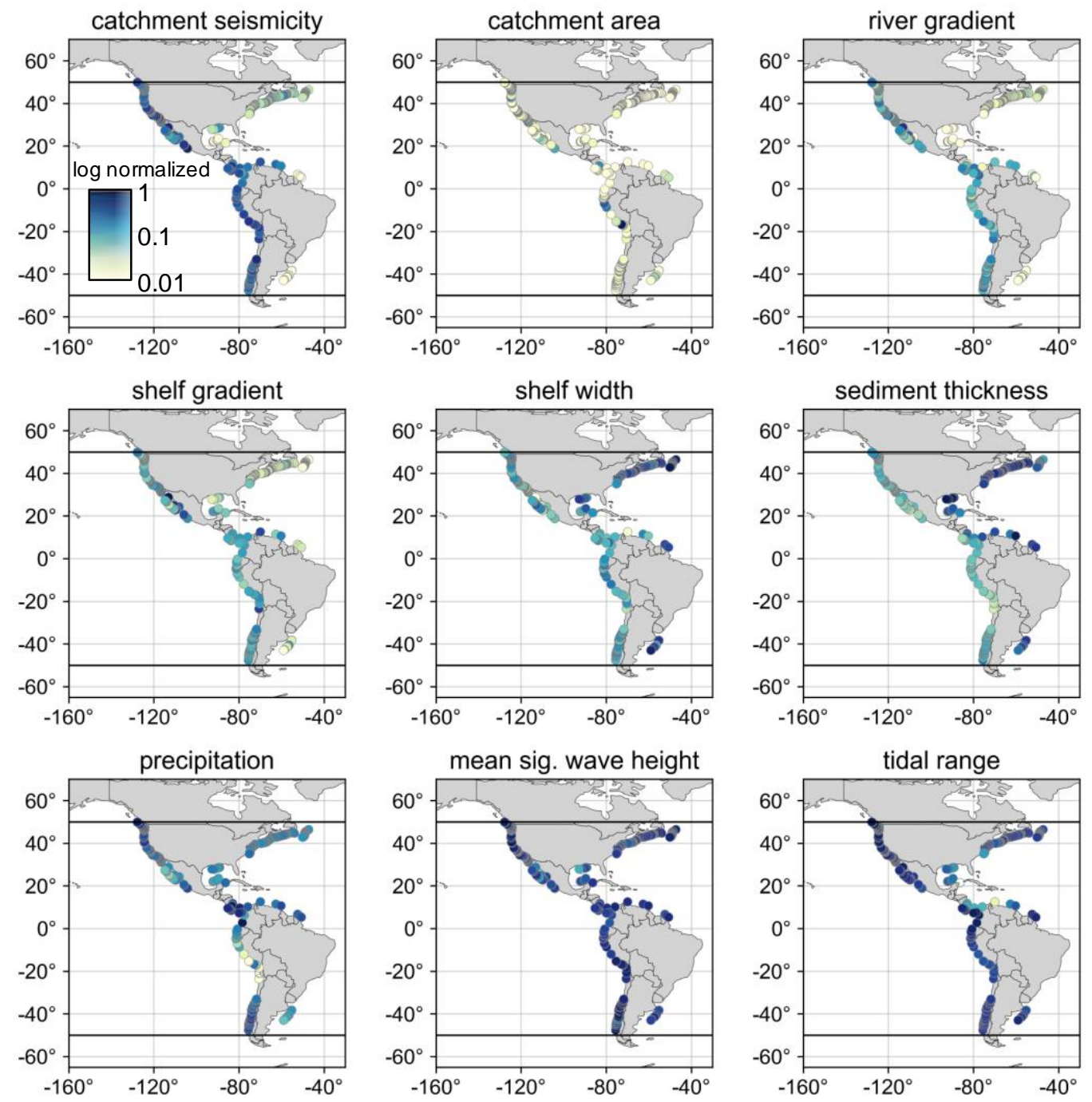

529 Fig. S2. Spatial distribution of canyons included in this analysis and six of the weighted tectonic, 530 geomorphic and climatic properties assigned to them (log-normalised for clarity). 
533 Table. S1: All data collected by this study (table of measured canyons and their associated indices).

534 Filename: 'prof_dist.csv'.

535 Table. S2: Shapefile for filtering canyons affected by gridding. Filename: Filename: 'filter.shp'.

536 Data S1: iPython notebook used for plotting all figures. This notebook will reproduce Figs 3. and 4 with

537 Table S1 and S2. Figure 1 (maps) requires download of open-source data cited in text, or can be sent from 538 author upon request. 